\title{
Hat Sanatı Araç Gereçlerinin Korunduğu Hattat Sandıkları: Ankara Etnografya Müzesinden Örnekler ${ }^{*}$
}

\author{
Hacer KARA** (iD
}

ÖZ

Yazı iletişimin en önemli unsurlarından biridir. Tarihi süreçte Türk İslam sanatında yazının sanatla olan ilişkisine bakıldığında, hüsn-i hat sanatının iletişim bağlamında çok büyük bir öneme sahip olduğu görülmektedir. Bu sebeple hat sanatının icrasında kullanılan başta kamış kalem olmak üzere kâğıt, mürekkep, hokka, makas, kalemtıraş, makta, mühre, divit, kalemdan vb. araç gereçleri döneminin iletişime kaynaklık eden araçları olarak görmek mümkündür. Dolayısıyla yazının yazılmasına kaynaklık eden bu iletişim araçlarının korunup saklandığ1 Ankara Etnografya Müzesindeki hattat sandıkları, sanat ve iletişim bağlamında bu yazının konusunu teşkil etmektedir. Bu çalışmayla, yayınlarda pek rastlamadı̆̆ımız hattat sandıklarının Ankara Etnografya Müzesi’ndeki örneklerini tanıtarak bilim dünyasına sunmayı amaçladık. Ankara Etnografya Müzesi hat sanatına ilişkin araç gereçler bakımından oldukça zengin bir koleksiyonu bünyesinde barındırmaktadır. Koleksiyonda bulunan dört adet hattat sandığı müzeden temin edilerek konumuz kapsamında malzeme, teknik, form ve süslemeleri bakımından ayrıntılı bir biçimde, diğer müzelerde bulunan bazı örneklerle de kıyaslanarak incelenmiștir. Eserlerin tamamı ahşaptan yapılmıștır. Kakma, çift katlı rölyef ve Edirnekâri (boyama) teknikleriyle süslenen dikdörtgen formlu bu dört örnekten biri çekmece, üçü ise kutu şeklinde tasarlanmıştır. Eserlerde basit geometrik motifler, doğada gördüğümüz biçimde çeşitli hayvan figürleri, yaprak ve gül gibi natüralist bitkiler ile barok-rokoko tarzı motifler bezeme ögesi olarak karşımıza çıkmaktadır. Üzerlerinde yapım tarihi, üretim yeri ve yapan ustasına ilişkin herhangi bir bilgi bulunmayan örneklerin süsleme özelliklerinden yola çıkılarak geç dönem Osmanlı eserleri oldukları tespit edilmiştir.

Anahtar Kelimeler: Ankara Etnografya Müzesi, Hat Sanatı Araç Gereçleri, Hattat Sandıkları, Yazı Çekmeceleri, Yazı Kutuları

\section{Calligrapher Chests in Which Calligraphy Tools are Preserved: Examples from Ankara Ethnography Museum}

\begin{abstract}
Writing is one of the most important factors of communication. Considering the relationship between writing and art in Turkish-Islamic art in the historical process, it is seen that the art of wishful calligraphy has a great importance in the context of communication. For this reason, especially the reed pen used in the execution of calligraphy; paper, ink, inkwell, scissors, sharpener,end grain, burnisher, dip pen, pen, etc. it is possible to see tools as communication resources of the era of tools. Therefore, calligraphers' chests in the Ethnographic Museum of Ankara, where these communication tools that are the source of the writing are preserved and stored, are the subject of this article in the context of art and communication. With this study, we aimed to present to the scientific world by introducing examples of calligrapher chests that we do not encounter in publications in the Ethnographic Museum of Ankara. Ankara Ethnography Museum contains a collection very rich in tools related to calligraphy. Four calligraphers' chests found in the collection were obtained from the museum and examined in detail in terms of material, technique, form and decorations within the scope of our topic, comparing with some examples found in other museums. All of the works are made of wood. One of these four rectangular-shaped examples, decorated with inlay, double-layer relief and Edirnekâri (painting) techniques, is designed in drawer form and three in box form. In the works, simple geometric motifs, various animal figures in the form we see in nature, naturist plants such as leaves and roses and baroque-rococo-style motifs are presented as appetizer elements. Examples that do not have any information about the date of construction, place of production and the master who made them were found to be late Ottoman artifacts based on their ornamental characteristics.
\end{abstract}

Keywords: Ankara Ethnography Museum, Calligraphy Tools, Calligraphy Chests, Writing Drawers, Writing Boxes

\section{Giriş}

"Duygu, düşünce veya bilgilerin, akla gelebilecek her türlü yolla başkalarına aktarılması, bildirişim, haberleşme, komünikasyon (URL-1, TDK, 2020).” olarak tanımlanan iletişim, sözlü olabildiği gibi yazılı olarak ta gerçekleşmektedir. Tarih boyunca kalıcı olması bakımından yazılı iletişim oldukça önemli bir yere sahiptir. İslam'ın yazılı bilgi ve belgeye verdiği önemin bir tezahürü olarak hat sanatı ilk olarak yazma eserlerde kendini göstermiş, özellikle de Mushaf yazımı Türkler eliyle önemli bir gelişme kaydetmiştir (Sülün, 2006, s. 2). Ayrıca asırlardır Tük İslam dünyasında hat sanatının yazılı iletişim bakımından bilginin

\footnotetext{
* Bu çalışma, 05-07 Kasım 2020 tarihleri arasında Konya'da düzenlenen "I. Uluslararası Konya Sanat Sempozyumu"nda, "İletişimde Kullanılan Hat Sanatı Araç Gereçlerinin Korunduğu Hattat Sandıkları: Ankara Etnografya Müzesinden Örnekler" başlığıyla sözlü olarak sunulmuş ve özet metni yayımlanmıştır. Ancak tam metni hiçbir yayında yer almamıştır.

** Dr. Öğr. Üyesi, Necmettin Erbakan Üniversitesi, hacerkara@erbakan.edu.tr

Makalenin Gönderim Tarihi: 09.03.2021; Makalenin Kabul Tarihi: 02.06.2021
} 
üretildiği ve aktarıldığ1 din-tasavvuf, edebiyat, tarih, felsefe, mantık, tıp, musiki vb. konulardaki çeşitli kitaplar ile tarih, kültür ve ekonomi açısından değerli bilgileri ihtiva eden ferman, berat, vakfiye gibi pek çok belgenin yazılmasında önemli bir yer tuttuğu görülmektedir. Bu bakımdan yazıllı iletişime kaynaklık ettiğini düşündügümüz hat sanatının icrasında kullanılan çeşitli araç gereçlerin ve onların korunup saklanmasında önemli olan hattat sandıklarının tanıtılmasına yönelik çalışmalara ihtiyaç duyulmaktadır. Bu bağlamda konumuz "Hat Sanatı Araç Gereçlerinin Korunduğu Hattat Sandıkları: Ankara Etnografya Müzesinden Örnekler" başlı̆ıııı taşımaktadır. Bu konuyu seçmekteki en önemli amacımız, yazma eserler, mezar taşları ve mimari eserlerdeki hat sanatı üzerine yapılan araştırmaların sayısının giderek artmasına karşılık, hat sanatında kullanılan araç gereçler ve onların korunması için kullanılan hattat sandıkları üzerine yapılan çalışmaların yok denecek kadar az olmasıdır. Bu çalışmayla Ankara Etnografya Müzesindeki ${ }^{1}$ hattat sandıkları malzeme, teknik, form, fonksiyon ve süsleme açısından ayrıntılı bir şekilde incelenerek literatüre bir nebze olsun katkıda bulunulmaya çalışılmıştır.

Konumuz kapsamında incelenen eserlerin tamamı müzenin teşhirinde yer almaktadır. Müzeden gerekli izinler alınarak eserlerin fotoğrafları ve bilgileri temin edilmiş, her bir eserin çizimleri yapılmışır. ${ }^{2}$ Çalışmamızda yer alan eserler, müzedeki envanter numaraları esas alınarak sıralanmıştır.

Konuya ilişkin yaptığımız literatür taramasında hattat sandıkları ile ilgili doyurucu bilgilere ulaşmak mümkün olmamıştır. Hat sanatına ilişkin bilgiler veren kaynaklarda pek çok hat sanatı araç gereci genel anlatımlarla tanıtılmıs, ahşap sanatı hususundaki kaynaklarda ise daha çok mimari ve mimariye bağlı ahşap eserler ya da çeşitli kullanım eşyaları üzerine bilgiler verilmiş ancak hattat sandıklarına neredeyse hiç değinilmemiştir. Ankara Etnografya Müzesindeki hattat sandıkları da herhangi bir yayına konu olmamıştır.

Sandık Mehmet Önder tarafından "İçerisine çeşitli eşyaların yerleştirildiği, genellikle tahtadan yapılan, kapaklı büyük kutu veya mahfaza (Önder, 1995, s. 170).” olarak tanımlanmaktadır. Celal Esat Arseven çekmeceyi "İçinde çekmeceleri olan küçük sandık veya kutu. Ufak tefek ve kıymetli şeyleri koymaya mahsus küçük sandık (Arseven, 1983, s. 383)." şeklinde tanımlarken, Erdem Yücel "İçinde değerli eşya saklanan küçük sandık. İsmini masa, dolap, konsol gibi mobilyaların içerisine yerleştirilip dışarıya doğru çekilebilen aynı addaki gözlerden alır (Yücel, 1993, s. 251).” şeklinde tarif etmektedir. Çekmecelerin değerli eşyaların konulduğu, Kur'ân çekmeceleri, sakal-1 şerif çekmeceleri, mücevher çekmeceleri, para çekmeceleri, çamaşır çekmeceleri, yazı çekmeceleri gibi isimler alarak, farklı alanlarda kullanılmak üzere yapıldıkları anlaşılmaktadır (Yücel, 1993, s. 252). Konumuz kapsamında incelediğimiz Ankara Etnografya Müzesindeki eserlerin tanımı konusunda bir dil birliği olmadığı gözlenmektedir. Örneğin bazı eserlerin envantere "çekmece" olarak kaydedildiği görülmüş, buna karşlık aynı eser vitrinde "yazı kutusu" olarak tanıtılmıştır. Kaynaklarda da bu tür eserler için çekmece-yazı çekmecesi teriminin daha çok tercih edildiği görülmektedir (Arseven, 1983, s. 383; Yücel, 1993, s. 251-252; Önder, 1995, s. 39, 204). Ancak biz yaptığımı bu spesifik çalışmanın başlığında ve metin içindeki anlatımlarımız sırasında eserlerin şeklini ortaya koyması bakımından daha kapsayıcı ve açıklayıcı olduğunu düşündüğümüz "hattat sandığı" terimini kullanmayı tercih ettik.

Hattat sandıkları, hattatların kamış kalem, kâğıt, hokka, makta, kalemtraş, kâğıt makası gibi kullandıkları çeşitli araç gereçleri muhafaza ettikleri ve topluca bulundurdukları eserlerdir. Abanoz, ceviz, meşe, gül ağac1, gibi sert ağaçlardan (Önder, 1995, s. 39), dikdörtgen prizma şeklinde yapıllp, iç kısımları çoğunlukla kadife, atlas ve çuha kumaşla kaplanmaktadır (Önder, 1995, s. 204; Yücel, 1993, s. 251). Hattat sandıklarının yazı masası olarak kullanıldıkları da bilinmektedir (Yücel, 1993, s. 252; Acar, 1999, s. 63). Taşınabilir eserler olmaları ve büyük bir bölümünün üzerinde herhangi bir kayıt bulunmaması sebebiyle hattat sandıklarının tarihi seyrini tespit etmek oldukça zordur. Ancak kaynaklardan anlaşıldığı kadarıyla 15. yüzyıl Timurlu döneminden birkaç örnek Topkapı Sarayı Müzesinde bulunmaktadır (Anonim, 1956, s. 4-5, 14). Süheyl Ünver'in belirttiğine göre, en k1ymetlileri halen Topkap1 Saray1 Müzesi'nde bulunan çekmecelerin imzalı olanları da mevcuttur. Ünver, bunlardan birinin Sultan Ahmet Camii Mimarı Mehmet Ağa (Çobanoğlu, 2003, s. 430-431)'nın imzasını taşıdığını belirtmektedir (Ünver, 2010, s. 46). Evliya Çelebi 17. yüzyılda İstanbul'da beş yüz kadar sedefkâr ve bin civarında kutucu olduğunu bildirmektedir

\footnotetext{
${ }^{1}$ Ankara Etnografya Müzesinde, aynı koleksiyon içerisinde bulunan hat sanatı araç gereçlerinden "maktalar" başka bir araştırmanın konusu olarak yayımlanmıştır (Bkz. Kara \& Aygör, 2020).

${ }^{2}$ Çizimleri yapan Necmettin Erbakan Üniversitesi, Sanat Tarihi Bölümü Yüksek Lisans Öğrencisi Esra Çiçek’e teşekkür ederim.
} 
(Şehsüvaroğlu, 1987, s. 16). Çeşitli kaynaklarda da 16-17. yüzyıllarda çekmece yapımının önemli bir sanat dalı olduğu, 18. yüzyıla kadar sedef, bağa, fildişi ve değerli taşlar kakılarak süslenen eserlerin bu yüzyıldan sonra barok, rokoko, ampir üsluplarının etkisiyle, diğer tekniklerin yanı sıra Edirnekâri ve lake teknikleri de ilave edilerek tezyin edildiği belirtilmektedir (Yücel, 1993, s. 252; Önder, 1995, s. 39). Günümüzde hattat sandıklarına Topkapı Sarayı Müzesi³ ${ }^{3}$ Türk ve İslam Eserleri Müzesi, Sakıp Sabancı Müzesi (Kollektif, 2012, s. 250, 252, 254), Konya Müze Müdürlüğü (Kara, 2020, s. 183), Ankara Etnografya Müzesi ve baz1 özel koleksiyonlarda rastlamak mümkündür.

\section{Hattat Sandıkları}

\subsection{Envanter Numaralı Hattat Sandığ1}

Müzenin 6000 envanter numarasina kayıtlı olan hattat sandığı, İstanbul Türk Etnografya komisyonu tarafindan 5 liraya satın alınarak müzeye kazandırılmışır. Eser Yazma Eserler Salonu/3 Nolu Vitrinde sergilenmektedir (Fotoğraf 1,2). Ceviz ağacından yapılan ve özgün renginde bırakılan dikdörtgen prizma biçimli hattat sandığ1 envantere çekmece olarak kaydedilmekle birlikte, kutu şeklinde tasarlanmış ve vitrindeki tanıtım yazısına da "yazı kutusu" olarak yazılmıştır. Eni $23,70 \mathrm{~cm}$, boyu $35,50 \mathrm{~cm}$, yüksekliği ise $10,00 \mathrm{~cm}$ ölçülerinde olan eserin üzeri iki parça olarak hazırlanan kapakla örtülmektedir. Uzun kenarlara menteşeyle tutturulan bu iki bölümlü kapağın bir kanadı bir yönden, diğer kanadı diğer yönden kutunun üzerini kaplayacak ve ortada hafif bombe oluşturacak biçimde kapanmakta ve kilitlenmektedir. Ancak anahtarı günümüze ulaşmamıstır.

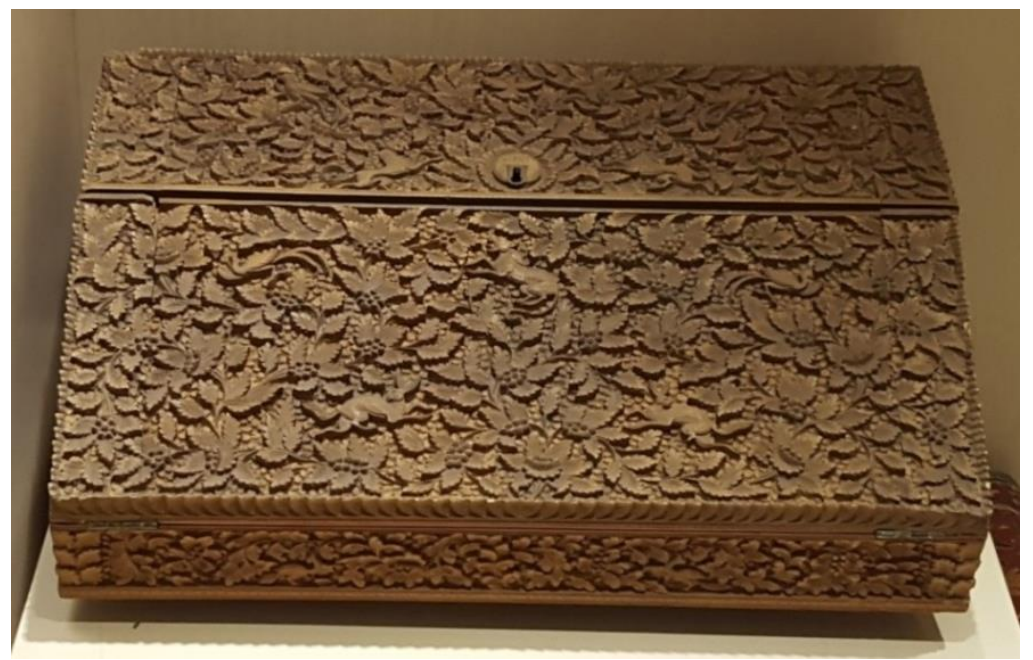

Fotoğraf 1: 6000 Envanter Numaralı Hattat Sandığı (Fotoğraf: Hacer Kara)

\footnotetext{
${ }^{3}$ Topkapı Sarayı Müzesi ile Türk ve İslam Eserleri Müzesinde bulunan farklı fonksiyonlara sahip 72 adet çekmecenin bir listesi için bkz. (Anonim, 1956).
} 


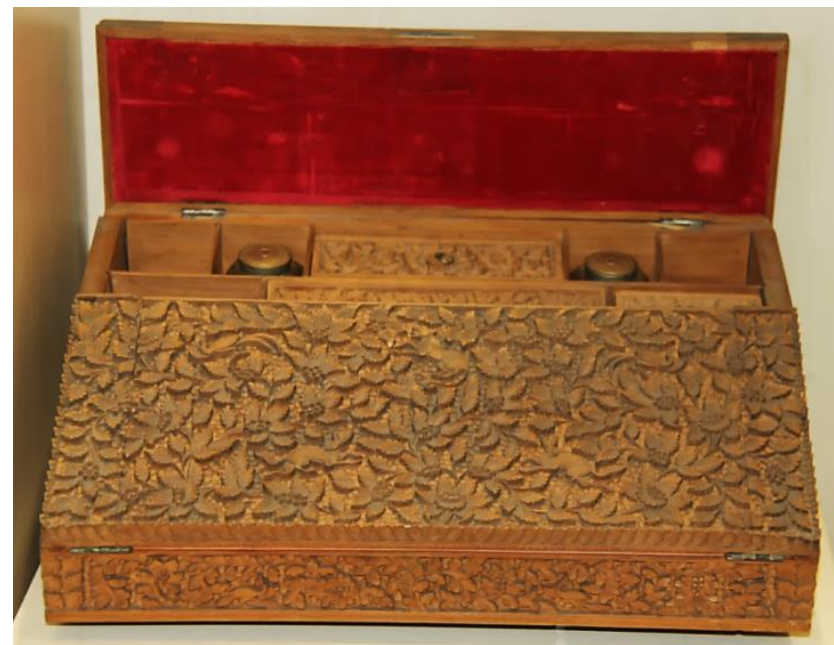

Fotoğraf 2: 6000 Envanter Numaralı Hattat Sandığ1 (Fotoğraf: Hacer Kara)

Dikdörtgen biçimli kutunun iç kısmı üç bölüme ayrılmıştır. Bu bölümlerden biri büyükçe bir dikdörtgen, diğer ikisi ise daha dar dikdörtgenler şeklindedir. Dar dikdörtgenlerden ilki, iki kenardaki daha küçük, ortadaki ise daha büyük olacak şeklide üç parçaya bölünmüştür. Bu bölümlerin tamamı kapaklıdır. İkinci dar dikdörtgen bölüm ise kenarlarda ikişerden dört küçük kare, ortada ise kapaklı bir dikdörtgen bölme bulunacak şekilde düzenlenmiştir. Bunlardan ikisinde metal kapaklı iki adet cam hokka mevcuttur. Kutunun ve kapakların iç kısmı kırmızı renkli kadife kumaşla kaplanmıştır (Fotoğraf 3, 4, 5, 6).

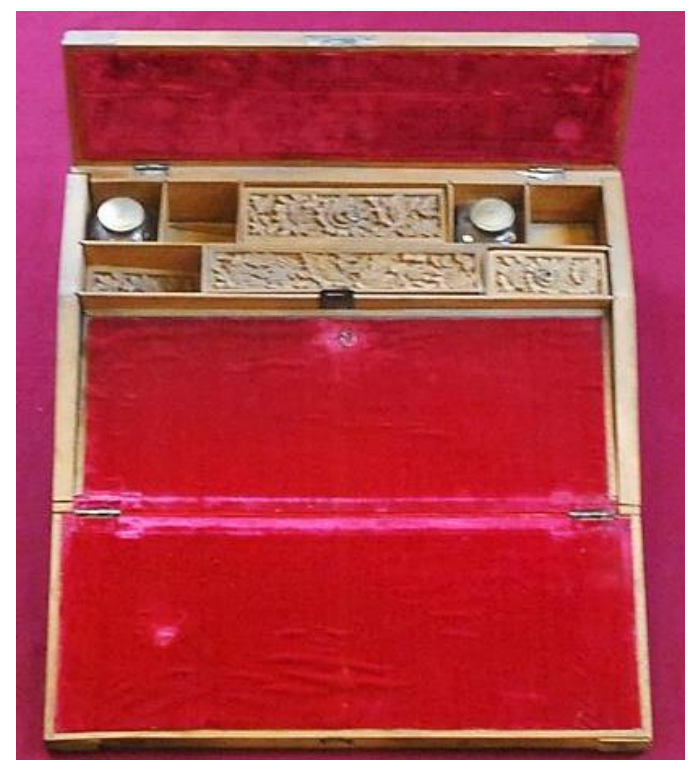

Fotoğraf 3: 6000 Envanter Numaralı Hattat Sandığının İç kısmı (Fotoğraf: Ankara Etnografya Müzesi)

Eserin dış kapakları ve ön kenarı ile iç kısımda yer alan kapaklar süslenmiştir. Boş yer bırakılmayacak biçimde oldukça girift bir bezemeye yer verilen kapaklarda çift katlı rölyef ve kazıma tekniği görülmektedir. Süslemenin alt zemininde küçük noktalar zeminin tamamını kaplamaktadır. Onun üzerinde ise ortalarında tomurcukları bulunan, kenarları dilimli iri çiçekler, yapraklar ve bunların arasına yerleştirilmiş hayvan figürleri dikkati çeker. Kapağın alt kısımlarında başlarını arkalarına dönmüş, karşılıklı koşar vaziyette resmedilen, bolluk ve bereketin sembolü iki adet tavşan figürü görülmektedir. Üst kısımda ölen insanların ruhunu ve cenneti temsil eden, iki yana simetrik olarak yerleştirilmiş ve dışa bakan kuş figürleri mevcuttur. Ortada sadakatin timsali, koşar vaziyette bir köpek figürü yer almaktadır. Ağıları, burunları, kulakları, 
kuyrukları ve vücut hatları bakımından figürlerin son derece gerçekçi çizildiği söylenebilir. Yaprakların tamamının yüzeyi ise kazıma tekniğinde işlenmiştir (Fotoğraf 1, 2, 7 Çizim 1).

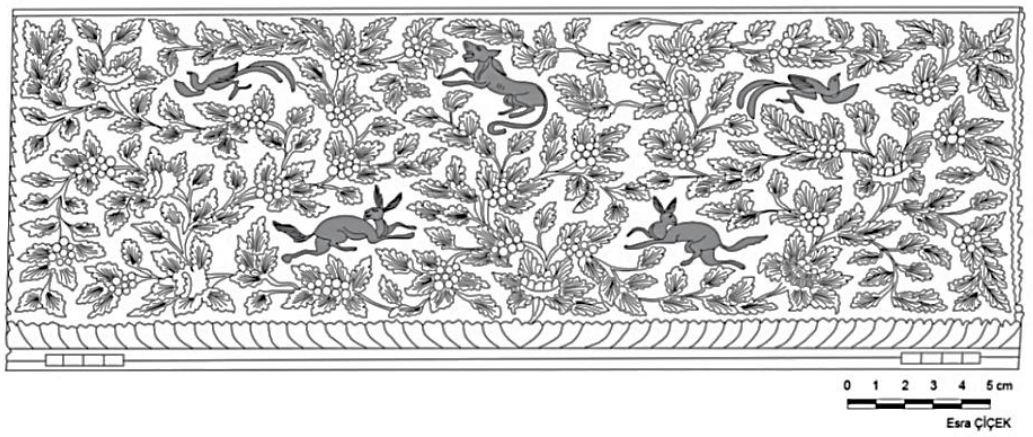

Çizim 1: 6000 Envanter Numaralı Hattat Sandığının Kapağı (Çizim: Esra Çiçek)

Eserin diğer yöne açılan kapağında da bitkisel bezemeler aynen tekrar edilmekle birlikte, kilit bulunan kısmın hatayi benzeri bir motif içine yerleştirildiği görülmektedir. Hemen bunun iki yanında Türk sanatında güç ve kuvvet sembolü olan birer aslan figürü simetrik bir şekilde yerleştirilmiştir. Hareketli bir biçimde ele alınan aslanların yüzü cepheden, gövdeleri ise profilden verilmiştir. Bu kapağın üst kısmında ise diğer kapaktaki kuş figürleri köşelere biraz daha yakın ve dışa bakar vaziyette tekrar edilmiştir (Fotoğraf $1)$.

Kutunun ön kısmında aynı bitkisel kompozisyon tekrarlanmış, burada yine hareketli biçimde ve başları içe doğru bakan karşıllkklı iki kuş figürüne yer verilmiştir (Fotoğraf 2, Çizim 2).

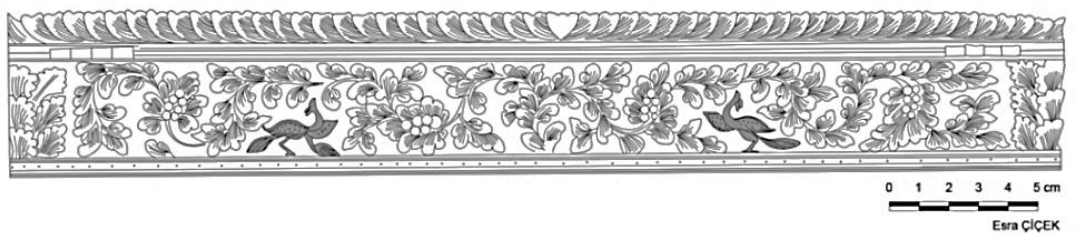

Çizim 2: 6000 Envanter Numaralı Hattat Sandığının Ön Kısmı (Çizim: Esra Çiçek)

Eserin içindeki bölmelerin üzerini örten iki küçük dikdörtgen kapağın ortasında büyük bir çiçek ve çiçeğin ortasına yerleştirilen metal tutma halkası, kenarlarda ise içi tomurcuklu çiçek ve yapraklara yer verilmiştir (Fotoğraf 4, Çizim 3). Hokkaların bulunduğu kısımdaki kapakta yine ortada bir çiçek ve çiçeğin ortasında halka bulunmaktadır. Bu çiçeğin iki yanında içi tomurcuklu çiçek ve yapraklar tekrar edilmiştir (Fotoğraf 5, Çizim 4). Bölmeleri örten en uzun kapakta ise bitkisel kompozisyonlar ve hareket halinde karşılıklı iki kuş figürü mevcuttur (Fotoğraf 6, Çizim 5).
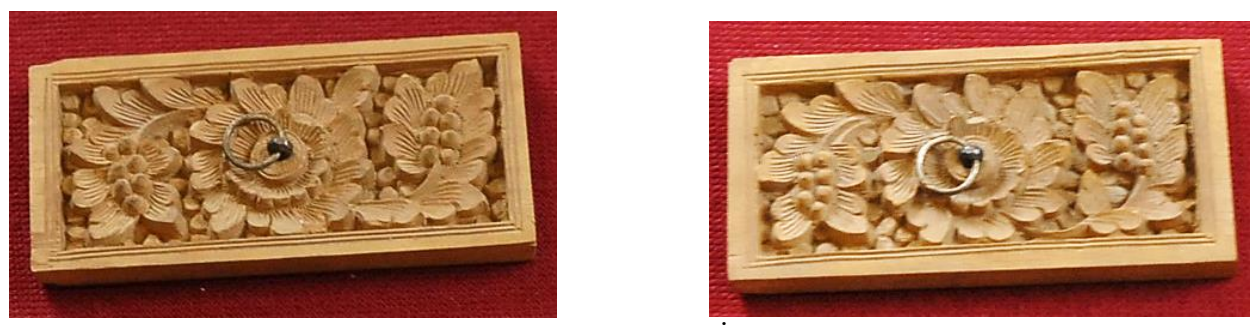

Fotoğraf 4: 6000 Envanter Numaralı Hattat Sandığının İç Bölmelerinin Kapakları (Fotoğraf: Ankara Etnografya Müzesi) 


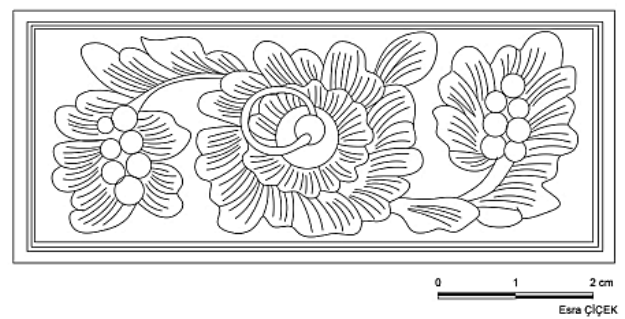

Çizim 3: 6000 Envanter Numaralı Hattat Sandığının İç Bölmelerinin Kapağı (Çizim: Esra Çiçek)

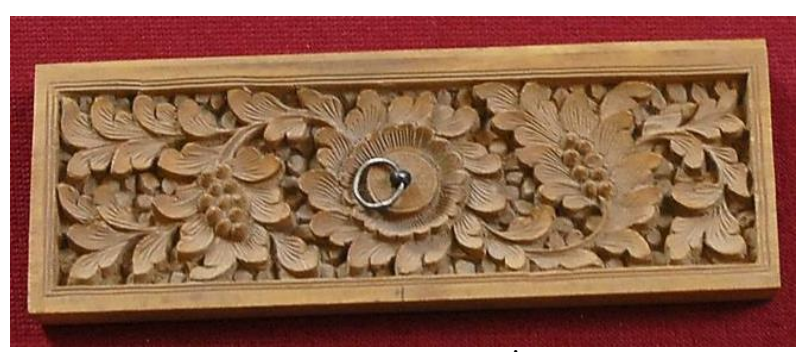

Fotoğraf 5: 6000 Envanter Numaralı Hattat Sandığının İç Bölmelerinin Kapağı (Fotoğraf: Ankara Etnografya Müzesi)

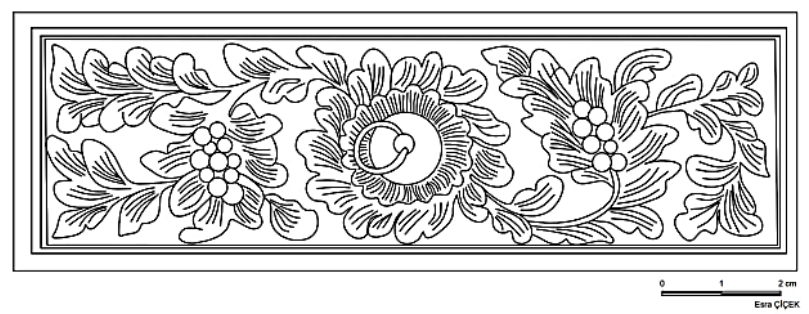

Çizim 4: 6000 Envanter Numaralı Hattat Sandığının İç Bölmelerinin Kapağı (Çizim: Esra Çiçek)

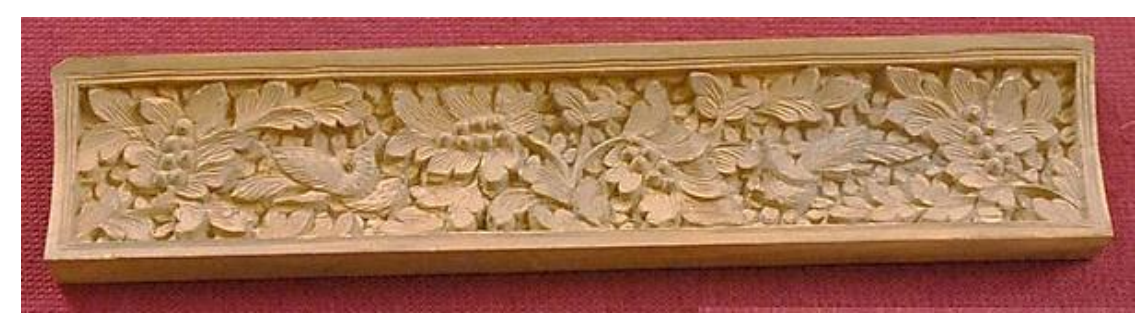

Fotoğraf 6: 6000 Envanter Numaralı Hattat Sandığının İç Bölmelerinin Kapağ1 (Fotoğraf: Ankara Etnografya Müzesi)

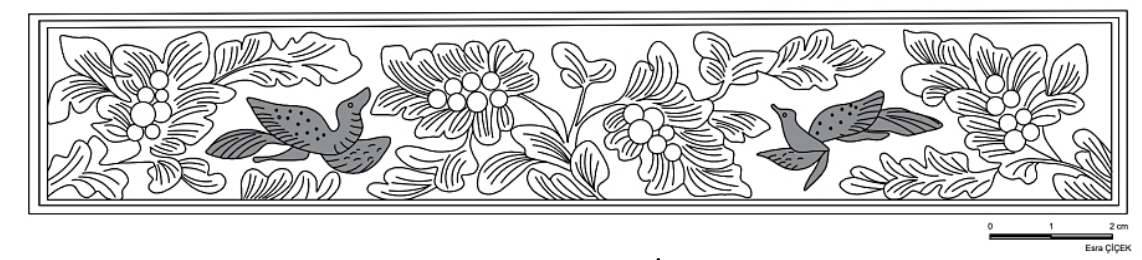

Çizim 5: 6000 Envanter Numaralı Hattat Sandığının İç Bölmelerinin Kapağı (Çizim: Esra Çiçek) 


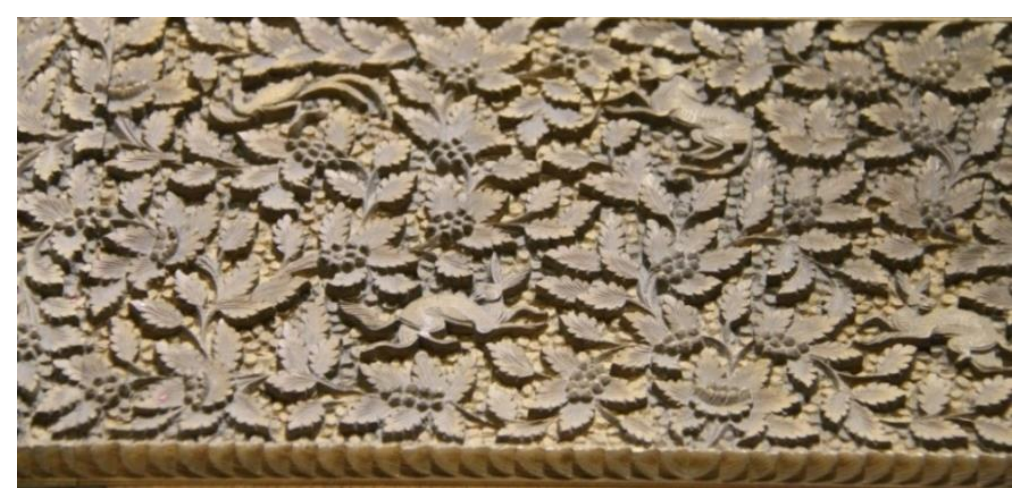

Fotoğraf 7: 6000 Envanter Numaralı Hattat Sandığının Süslemelerinden Detay (Fotoğraf: Hacer Kara)

Hattat sandığının üzerinde herhangi bir kayıt olmadığından ustası, yapım yeri ve tarihi bilinmemektedir. Eserin üzerindeki motifler ve motiflerin işleniş biçimi konumuz kapsamında incelenen diğerlerinden üslup bakımından biraz farklılık arz etmekle birlikte, eser envanter kaydında Osmanlı dönemine atfedilmiştir. Hattat sandığının üretim yeri bilinmese de, süslemelerinden yola çıkılarak Osmanlı döneminde, yaklaşık olarak 18-19. yüzylllarda yapıldığı düşünülebilir.

\subsection{Envanter Numaralı Hattat Sandığı}

Müzede 7169 envanter numarasına çekmece olarak kaydedilen hattat sandığı, envanter bilgilerine göre Sabık Ankara mebusu Sami Bey'den 25 liraya satın alınarak, 27.06.1931 tarihinde müzeye getirilmiştir. Yüksekliği $22 \mathrm{~cm}$, eni $18 \mathrm{~cm}$ ölçülerindeki eser günümüzde müzede Yazma Eserler Salonu/3 Nolu Vitrinde sergilenmektedir (Fotoğraf 8, 9).

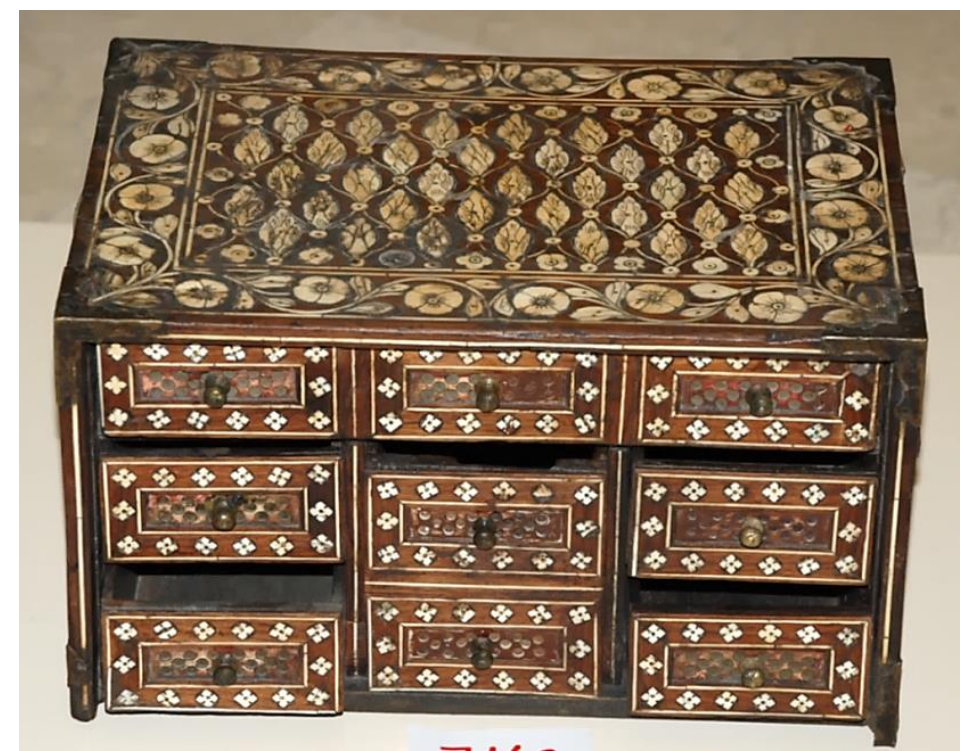

Fotoğraf 8: 7169 Envanter Numaralı Hattat Sandı̄̆̆ (Fotoğraf: Ankara Etnografya Müzesi) 


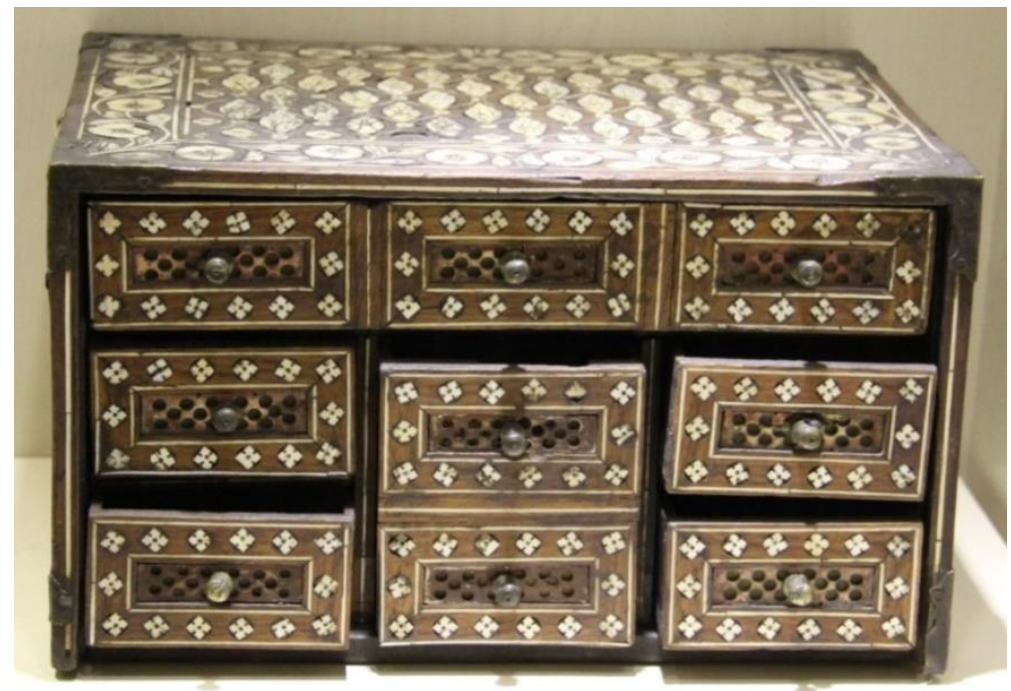

Fotoğraf 9: 7169 Envanter Numaralı Hattat Sandığının Ön Kısmı (Fotoğraf: Hacer Kara)

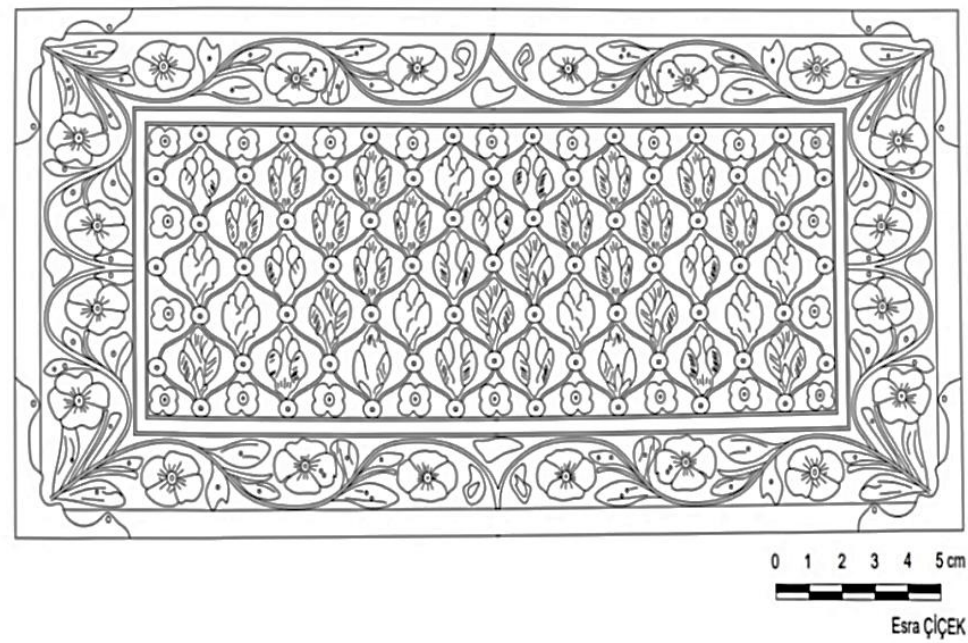

Çizim 6: 7169 Envanter Numaralı Hattat Sandığının Üst Kısmı (Çizim: Esra Çiçek)

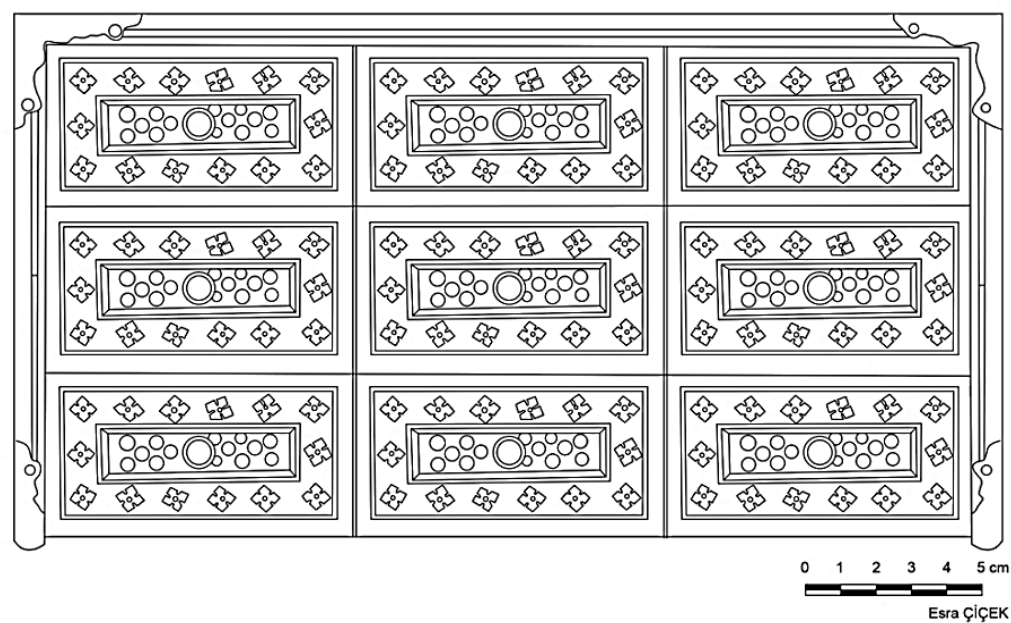

Çizim 7: 7169 Envanter Numaralı Hattat Sandığının Ön Kısmı (Çizim: Esra Çiçek) 
Ceviz ağacından fildişi kakma tekniğinde yapılan hattat sandığı dikdörtgen prizma şeklindedir. Üzerinde dokuz bölümlü görünmekle birlikte altı adet çekmece mevcuttur. Her iki yanda bulunan ikişerden dört adet çekmece eş büyüklüktedir. Üst kısımda yatayda üç çekmece gibi tasarlanan kısım bir bütündür. Ortada ise dikeyde iki ayrı çekmece gibi görünen kısımda yine bütün haldedir. Sandığın ön kısmını örten kapak kısmı günümüzde eksiktir (Fotoğraf 8).

Eserin üst kısmının dört kenarı, fildişi kakma yapılarak oluşturulan ince cetveller arasında bulunan kıvrım dalların taşıdığı yapraklar ve dört yapraklı çiçek motifleriyle süslenmiştir. Ortadaki kısım ise ince fildişi kakma çizgilerle küçük kartuşlara bölünerek, kartuşların birleşme kısımlarına noktalar, iç kısımlarına ise bu noktalardan yukarı doğru yükselen çiçek motifleri yerleştirilmiştir. Ayrıca köşelerde ve kenarlarda kartuşların arasındaki boşluklarda da dört yapraklı çiçekler görülmektedir (Fotoğraf 8, Çizim 6). Çekmecelerin her biri fildişi kakma ince çizgilerle sınırlandırılmış, içine 14 adet dört yapraklı çiçek motifi yerleştirilmiştir. Çekmecenin tam ortasında oluşan dikdörtgen biçimli alanda ajur tekniğinde daire şeklinde küçük oyuklarla süslenmiş metal bir parça ve bunun da ortasında metal tutamak kısmı görülmektedir (Fotoğraf 9, Çizim 7).

Süslemelerinden yola çıkarak 18-19. yüzylla tarihlendirilebileceğimiz eserin muhtelif yerlerinde çatlaklar ve fildişi malzemenin döküldüğü gözlenmektedir.

\subsection{Envanter Numaralı Hattat Sandığ}

Müzenin 8458 envanter numarasına kayıtlı olan sandığın eni $21,50 \mathrm{~cm}$, boyu $54,50 \mathrm{~cm}$, yüksekliği $9 \mathrm{~cm}$ ölçülerindedir. İstanbul Zincirli Han No:5 Antikacı Ediz Bey'den 8 liraya satın alınarak, 25.09.1934 tarihinde müzeye getirilmiştir. Envanterde çekmece olarak kaydedilen eser, vitrinde "yazı kutusu" olarak tanitılmıştır (Fotoğraf 10).

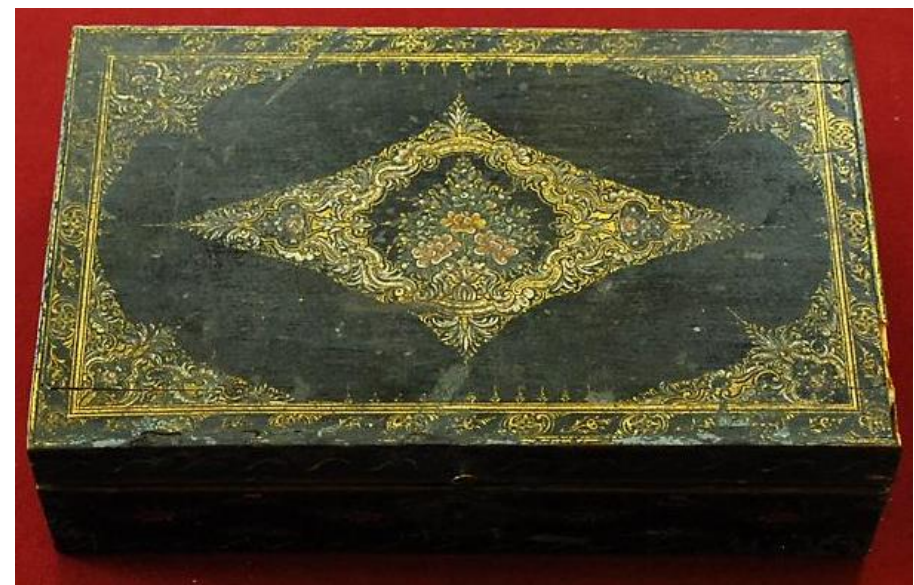

Fotoğraf 10: 8458 Envanter Numaralı Hattat Sandığ1 (Fotoğraf: Ankara Etnografya Müzesi)

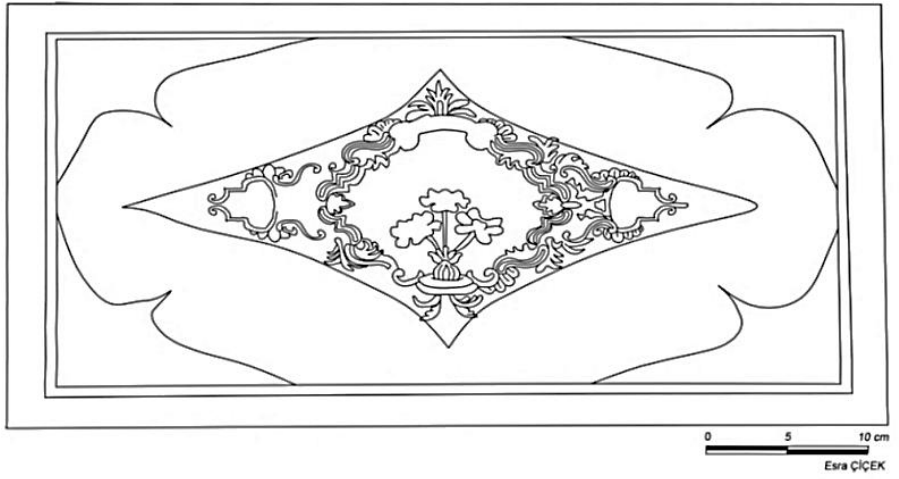

Çizim 8: 8458 Envanter Numaralı Hattat Sandığının Üst Kısmı (Çizim: Esra Çiçek) 
Yazma Eserler Salonu/Yazma Vitrininde sergilenen ahşap malzemeden yapılmış hattat sandığı, dikdörtgen prizma formlu bir kutu şeklinde olup, kilidi bulunmaktadır. Hem dış hem de iç kısmı Edirnekâri (boyama) tekniğinde süslenmiştir. Dış kısmı siyaha boyanan sandığın kapağında kitap kapaklarındaki tasarımların bir benzeri olarak ortasında eş kenar dörtgen şeklinde bir şemse, köşelerde köşebentler ve kenarlarında bordürler görülmektedir. Şemsenin ortasında "S" ve "C" kıvrımlarıyla oluşturulan boşluğun içine çiçek demetleri yerleştirilmiştir. Sandığın kenarları girlantların içinde yer alan çiçek demetleriyle süslenmiştir. Ağırlıklı olarak altının kullanıldığı bu bezemelerde Türk barok-rokoko üslubundaki bitkisel motifler tercih edilmiştir (Fotoğraf 10, Çizim 8).

Hattat sandığının iç kısmının zemini kırmızıya boyanmıştır. Burada kapağın ortasında "S" şeklinde dalgalar yaparak birbirinin içinden geçen beyaz ve siyah iki ipliğin ortada şemse benzeri bir motif oluşturduğunu söylemek mümkündür. Tam ortasına ise altınla Sultan Abdülmecid'in tuğrası yazılmıştır. Köşelerde yine kapağın dışında olduğu gibi barok-rokoko tarzı motiflerle yapılmış köşebentler dikkati çeker. Sandığın iki bölümlü iç kısmında dört adet hokkanın yerleştirilebileceği daire biçimli yuvalar oluşturulmuş, bu yuvaların arası yarım yıldızlarla süslenmiştir. Diğer kısımda hareketli olarak tasarlanan bölümün ortasında tuğraya yer verilmeyip çiçek demetleriyle süslenmiş ahşap bir tutamak yeri eklenmiştir. Burada da kapaktakinin benzeri bir şemse ve köşebentler yer almaktadır. Günümüzde eserin hokkaları mevcut değildir (Fotoğraf 11). Eserin kolayca taşınabilmesi için kısa kenarlara bronz kulplar yapılmıştır.

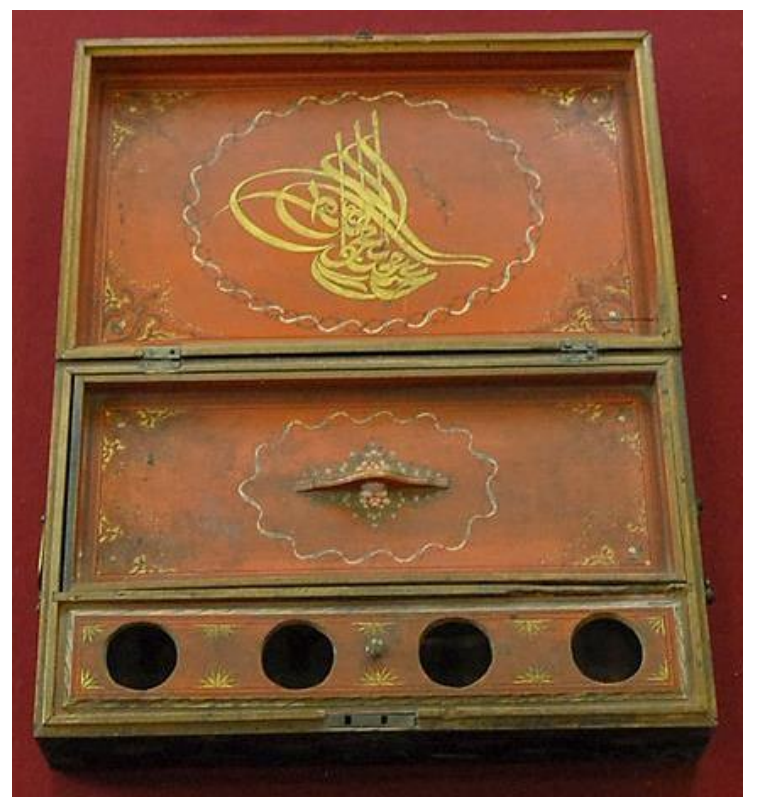

Fotoğraf 11: 8458 Envanter Numaralı Hattat Sandığının İç Kısmı (Fotoğraf: Ankara Etnografya Müzesi)

Hattat sandığının yapım tarihi ve ustasının kim olduğu bilinmemektedir. Ancak İstanbul'dan satın alınarak Ankara Etnografya Müzesine getirilen bu eserin iç kapağı üzerinde yer alan Abdülmecid tuğrasının varlığı, eserin onun yönetim yıllarında yapıldığını göstermektedir. İstanbul Türk ve İslâm Eserleri Müzesinde 210 envanter numarasina kayitlı olarak sergilenen, I. Abdülmecid (1255-1278/1839-1861) döneminde es-Seyyid Ömer el-Recai (Anonim, 2002, s. 318) tarafından yapılmış eser, bizim örneğimizle renkler ve ayrıntılar dışında tasarım bakımından neredeyse birebir benzemektedir. Bu bakımdan 8458 envanter numaralı eserimizin üretim yerinin de benzer örnekten yola çıkılarak İstanbul olduğu düşünülebilir.

\subsection{Envanter Numaralı Hattat Sandığ1}

Müzenin 10725 envanter numarasına çekmece olarak kaydedilen hattat sandığının yüksekliği $14,50 \mathrm{~cm}$, eni ise $32,50 \mathrm{~cm}$ ölçülerindedir. İstanbul evkafinın şehzade ambarından İstanbul müzeleri genel 
direktörlügünün 18.01 .1936 tarihli 116 saylı tezkeresiyle 25 liraya satın alınarak müzeye getirilmiştir. Sandık Yazma Eserler Salonu/3 Nolu Vitrinde sergilenmektedir (Fotoğraf 12, 13).

Ahşaptan yapılan hattat sandığ dikdörtgen prizma şeklindedir. Kutu şeklinde tasarlanan eserin piramidal görünümlü kapağ1 yana doğru açılmaktadır. Edirnekâri (boyama) tekniğinde süslenen hattat sandığının kapağının üst kısmında altına boyanmış dilimli oval bir şemse, uçlarında üç dilimli palmet şeklinde salbekler ve köşelerde köşebentler yer almaktadır (Çizim 9). Şemse yüzeyi pembe renkli güller ve kırmızı renkli beş yapraklı çiçeklerle süslenmiştir. Salbek ve köşebentlerde de aynı motifler kullanılmıştır. Bütün bu tasarımın çevresi üç iplik rumilerle süslü bir bordürle çevrelenmiştir. Kapağın yan kenarlarında bir gül, bir beş yapraklı çiçek şeklinde dönüşümlü sıralanan bitkisel süslemeye yer verilmiştir. Bu kısmın etrafı da yine rumilerle bezenmiştir. Sandığın kenar kısımları üç iplik rumilerle süslenen bordürlerle çevrelenmiş ve bunun ortasına yine pembe güller ile kırmızı renkli çiçekler yerleştirilmiştir (Fotoğraf 13, Çizim 10).

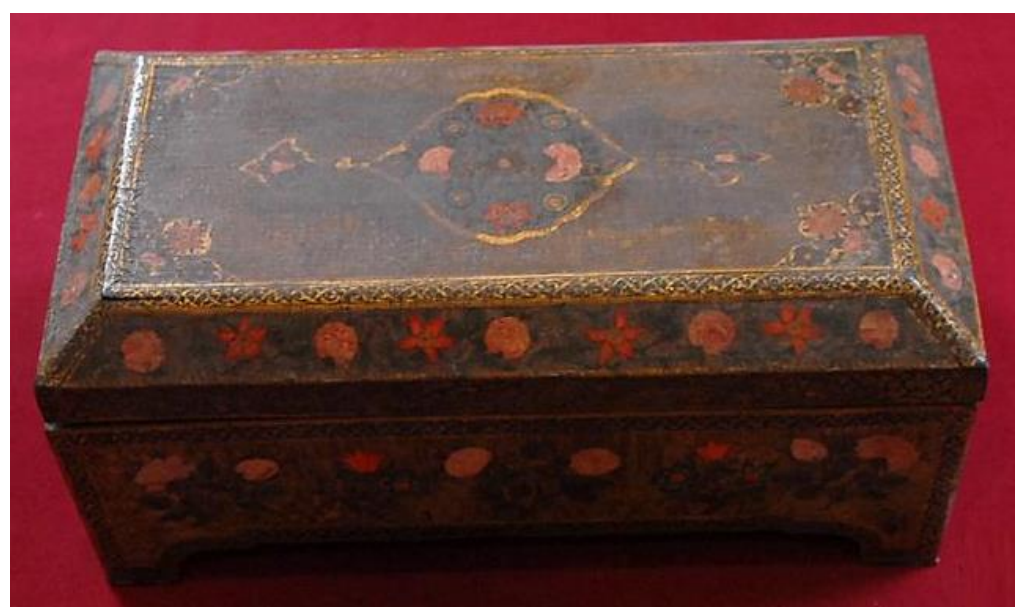

Fotoğraf 12: 10725 Envanter Numaralı Hattat Sandığ1 (Fotoğraf: Ankara Etnografya Müzesi)

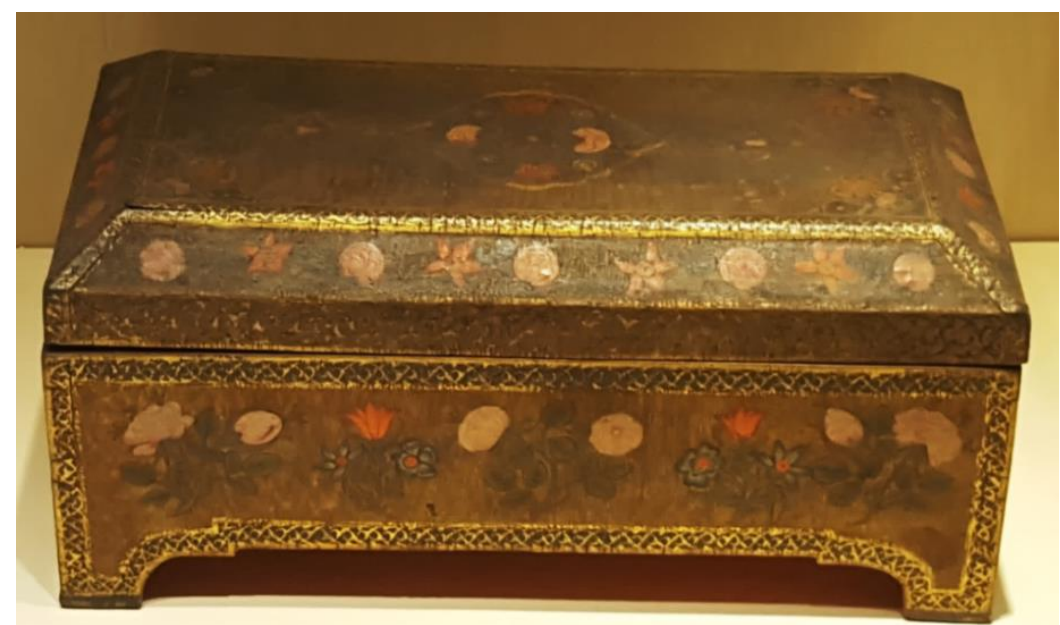

Fotoğraf 13: 10725 Envanter Numaralı Hattat Sandığının Ön Kısmı (Fotoğraf: Hacer Kara) 


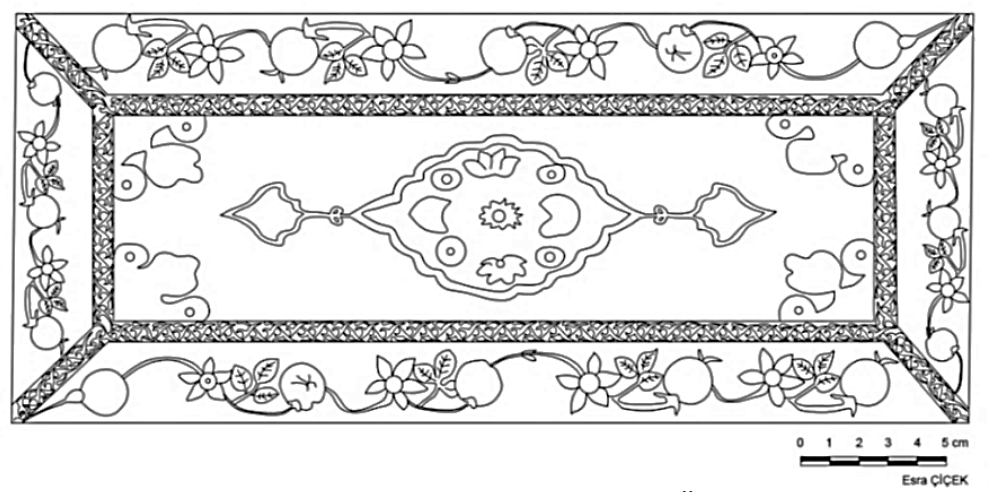

Çizim 9: 10725 Envanter Numaralı Hattat Sandığının Üst Kısmı (Çizim: Esra Çiçek)

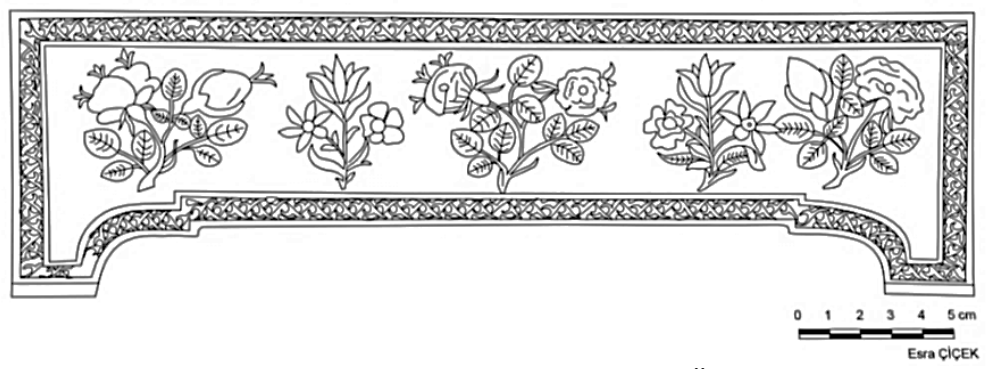

Çizim 10: 10725 Envanter Numaralı Hattat Sandığının Ön Kısmı (Çizim: Esra Çiçek)

İç kısmı kırmızıya boyanan hattat sandığının kapağı yine Edirnekâri tekniğinde natüralist bitkilerle tezyin edilmiştir. Eserin içinde küçük bir kapak daha mevcuttur.

Sandığın tarihine ilişkin herhangi bir veri bulunmamaktadır. Edirnekâri tekniğinde, tamamı natüralist motiflerden oluşan süslemelerinden yola çıkılarak eserin 19. yüzyılda yapıldığını söylemek mümkündür.

\section{Değerlendirme}

Çalışmamızda Ankara Etnografya Müzesinde bulunan, hat sanatında kullanılan araç gereçlerin taşındığı ya da başka bir deyişle korunup saklandığı, dört adet hattat sandığı (çekmece ve kutu) incelenmiştir. Malzeme, teknik, form, fonksiyon ve süsleme açısından ele aldığımız bu dört örneğin hiçbirinde yapım yeri, tarihi ve ustasının ismine rastlanmamıştır. Her ne kadar taşınabilir eserlerin üretim yerleri hususunda kesin bilgiler vermek zor olsa da eserlerden üçünün İstanbul'dan satın alınarak müzeye getirilmesi, üretim yerlerinin de İstanbul olabileceğini düşündürmektedir. Nitekim yukarıda bahsettiğimiz üzere 8458 numaralı eserin (Fotoğraf 10,11) bir benzeri İstanbul Türk ve İslâm Eserleri Müzesinde mevcuttur. Bir eser ise Ankara'dan elde edilmiştir (Fotoğraf 8). Tarihleri bilinmeyen eserlerin üzerlerinde kullanılan teknik ve bezeme kompozisyonlarından yola çıkılarak 18-19. yüzyıl özellikleri taşıdıkları söylenebilir.

\subsection{Malzeme ve Teknik}

Araştırmamızda yer alan dört örneğin tamamı ahşap malzemeden yapılmıştır. Dayanıklı olması sebebiyle bu tarz eserlerin yapımında genelde ceviz ağacının kullanıldığı bilinmektedir. Hattat sandıklarından ikisinin envanter kayıtlarında ceviz ağacından yapıldıkları belirtilirken, diğer ikisinin üzeri boyandığından kullanılan ahşabın cinsi ayırt edilememektedir. 6000 envanter numaralı eser ahşabın kendi doğal renginde bırakılmış (Fotoğraf 2), 7169 envanter numaralı eserde ise ahşabın rengi yakma usulüyle koyulaştırılmıştır (Fotoğraf 8).

6000 envanter numaralı sandığın kilit kısmı ile iç bölmelerinin kapaklarındaki kulplarda ve 8458 envanter numaralı sandığın kilit kısmında metal kullanılmışıtı. 7169 ve 8458 envanter numaralı iki hattat sandığının yan kısımlarında bronz malzemeden yapılmış taşıma kulpları mevcuttur. 
İncelenen eserlerin süslenmesinde farklı tekniklerin uygulandığı görülmektedir. 6000 envanter numaralı sandıkta çift katlı rölyef ve kazıma teknikleri (Fotoğraf 7), 7169 envanter numaralı sandıkta ise fildişi kakma ve ajur teknikleri (Fotoğraf 8) birlikte uygulanmıştır. 8458 (Fotoğraf 10, 11) ve 10725 envanter numaralı (Fotoğraf 12, 13) iki örnek Edirnekâri (ahşap üzeri boyama) tekniğiyle süslenmiştir. 8458 envanter numaralı sandığın diş ve iç kısmında Edirnekâri tekniği uygulanmakla birlikte, bezeme kompozisyonları birbirinden farklıdır (Fotoğraf 10, 11).

\subsection{Form ve Fonksiyon}

İncelenen eserlerin tamamı form bakımından dikdörtgen prizma şeklinde tasarlanmıştır. Örneklerden üçü diştan kutu şeklindedir (Fotoğraf 1, 10, 12). Bunlardan birinin kapağ1 iki parça olup iki yana doğru açılırken (Fotoğraf 1, 3), ikisinin kapağ1 tek parça olup bir yana doğru açılmaktadır (Fotoğraf 10, 12). İç kısmında çeşitli bölmelere sahip olan 6000 ve 8458 envanter numarasına kayıtlı kutularda hokkaların konulacağ1 ayrı bölmelere yer verilmişsir (Fotoğraf 3, 11). 7169 envanter numaralı eser ise altı adet çekmeceye sahiptir. Çekmecelerin ön kısmını kapatan bir kapağın varllğı köşelerdeki metal kısımlardan anlaşılmaktadır. Ancak bu ön kapak günümüze ulaşamamıştır (Fotoğraf 9).

Ahşap eserler içinde fonksiyon bakımından hattat sandığ1 (çekmece-kutu), kuyumcu (mücevher) sandığı, Kur'ân muhafazaları, sakal-1 şerîf kutuları gibi birçok farklı sandık ile karşılaşmak mümkündür. Aslında bunlar biçim ve ölçüler bakımından çoğu kez benzerlikler taşımakta ve dıştan bakılarak fonksiyonları hemen anlaşılamamaktadır. Ancak eserlerin iç kısımlarındaki tasarımlar ve müzelerdeki envanter bilgileri eserlerin fonksiyonu hakkında bize bilgi vermektedir. Yayınlarda zaman zaman farklı fonksiyonlara sahip bu tür eserlerle karşılaşmak mümkün olsa da hattat sandıklarının örnekleri yok denecek kadar azdır. Araştırmamız kapsamında incelenen eserlerin iç kısımlarının hat sanatında kullanılan kamış kalem, hokka, makta, makas vb. araç gerecin konulacağı bölmelere ayrilmasından ve müzedeki envanter bilgilerinden, fonksiyon olarak hat sanatına ilişkin araç gereçleri korumak ve derli toplu bulundurmak için yapıldıkları anlaşılmaktadır. 6000 envanter numaralı sandığın içinde bulunan iki adet metal kapaklı cam hokka (Fotoğraf 3) ve 8458 envanter numaralı sandıkta yer alan hokka yuvaları (Fotoğraf 11) bunun kanıtıdır. 7169 envanter numarasına kayıtlı çekmeceli örneğin vitrindeki tanıtım yazısında yazı çekmecesi olduğunun belirtilmesi fonksiyonu hakkında bize bilgi vermektedir. İç kısmı bölmelere ayrılan, içinde cam hokka, kalemlik vb. araç gereci barındıran bir başka hattat sandığı ise günümüzde Mevlâna Müzesinde sergilenmektedir. 1712 envanter numaralı bu sandığın alt kısmında kağıtları koyabilmek için ayrıca bir çekmece mevcuttur (Kara, 2020, s. 183).

\subsection{Süsleme}

İncelenen hattat sandıkları estetik açıdan son derece zarif bir biçimde tasarlanmış ve birbirinden farklı kompozisyonlarla süslenmiştir. Bu kompozisyonlar geometrik, figürlü, bitkisel motifler ve yazı ile oluşturulurken, nesneli süslemeye yer verilmemiştir. Aynı eserde birbirinden farklı motiflerin kullanıldığı da görülmektedir.

Geometrik süsleme 7169 envanter numaralı eserin çekmecelerindeki metal parçalar üzerinde, ajur tekniğinde işlenen küçük daireler şeklinde karşımıza çıkmaktadır (Fotoğraf 9, Çizim 7). 8458 envanter numaralı sandığın dış kapağında ise eşkenar dörtgen şeklinde bir şemse motifi yer almaktadır (Fotoğraf 10).

Bitkisel süsleme konumuz kapsamındaki tüm sandıklar üzerinde görülmektedir. Araştırmamızda yer alan 6000 envanter numaralı sandığın iki yana açılan kapaklarında, ön kısmında ve iç kısımdaki bölmelerin kapaklarında iri yapraklı tomurcuklu çiçekler ve yapraklardan müteşekkil bitkisel süslemenin oldukça girift bir biçimde işlendiği gözlenmektedir. 7169 envanter numaralı eserin üst kısmında kakma tekniğiyle kenar bordürü olarak kıvrım dalların taşıdığı çiçekler ve yapraklar yer alırken, çekmecelerde de dört yapraklı çiçekler mevcuttur (Fotoğraf 8, Çizim 6, 7). 8458 envanter numaralı eserde ise şemse ve köşebentlerde rokoko tarzında çiçekler görülmektedir (Fotoğraf 10, Çizim 8). 10725 envanter numaralı sandığın kapağında ve kenarlarında natüralist bir anlayışla gül ve çeşitli çiçekler resmedilirken, kenar bordürlerinde rumiler yer almaktadır (Fotoğraf 13, Çizim 9, 10).

Figürlü süsleme yalnızca 6000 envanter numaralı eserin her iki kapağının dışında, kutunun ön dış kısmında ve iç bölmelerden birinin kapağı üzerinde görülmektedir. Burada Türk sanatında sıklıkla 
karşılaşılan aslan, köpek, tavşan ve kuş figürleri resmedilmiştir (Fotoğraf 1, 6, Çizim 1, 2, 5). Üzerinde kilit bulunan kapakta, kilidin her iki yanına simetrik olarak yerleştirilen iki aslan figürü mevcuttur. Birçok kültürde güç, kuvvet ve taht sembolü olan aslan, Türk Sanatında daha çok Budizm’le birlikte ortaya çıkmıs, İslamiyet'ten önce ve sonra en çok kullanılan figürlerden olmuştur (Çoruhlu, 2002, s. 136-137; Çoruhlu, 2014, s. 89, 101). İslamiyet’ten sonra ise aslanın Türkler arasında Hz. Ali’nin sembolü olarak da kullanıldığ1 görülmektedir (Çoruhlu, 2014, s. 92). Diğer kapakta yer alan köpek, İslamiyet'ten sonra av ile ilişkilendirilerek dostluk, sadakat, sabır ve tevekkülün sembolü olarak kullanılan bir figürdür (Çoruhlu, 2002, s. 155). Aynı kapakta simetrik olarak yerleştirilen iki tavşan figürü bulunmaktadır. On iki hayvanlı takvimdeki yıl simgelerinden biri olan ve Göktürkler döneminde av hayvanı olarak görüldüğü için uğurlu sayılan tavşan, İslamiyet'ten sonra bolluk, kurnazlık ve iyi şansın sembolü olarak karşımıza çıkmaktadır (Çoruhlu, 2002, s. 156). Sandığın her iki kapağında, ön kısmında ve iç kapaklardan birinde simetrik olarak yerleştirilen kuş figürleriyle karşılaşılmaktadır. Türk sanatında daha çok ruh sembolü olarak kabul edilen kuşlar, cenneti de temsil etmektedir (Çatalbaş, 2011, s. 53). Bahsi geçen bütün bu figürler girift bir bitkisel kompozisyon içerisinde birbirinden ayrı, simetrik ve hafif hareketli vaziyette resmedilmiştir. Figürlerin vücutlarındaki noktaların ve çizgilerin bile son derece ayrıntılı biçimde işlendiği gözlenmektedir (Fotoğraf 7, Çizim 1, 5).

Yazı, eserlerden yalnızca 8458 envanter numaralı hattat sandığının kapağının iç kısmında yer almaktadır. Burada kırmızı zemin üzerine altınla yazılan Sultan Abdülmecid’in tuğrası görülmektedir (Fotoğraf 11).

\section{Sonuç}

Türk İslam sanatlarında oldukça önemli bir yere sahip olan hat sanatı, usta hattatlar eliyle yüzyıllar boyunca gelişerek günümüze kadar ulaşmıştır. Bu sanatı icra eden hattatlar kendileri için özenle hazırlanan son derece estetik ve kimi zaman değerli taşlarla ve madenlerle süslenen araç gereçleri kullanmışlardır. Bu denli değerli malzemelerden yapılan araç gereçlerin topluca bir arada bulundurulması ve korunması için tarihi süreçte çok süslü hattat sandıklarının yapıldığı görülmektedir.

"Hat Sanat1 Araç Gereçlerinin Korunduğu Hattat Sandıkları: Ankara Etnografya Müzesinden Örnekler" adlı bu çalışmamızda, dört adet hattat sandığı incelenmiştir. Eserlerin üçünün İstanbul'dan, birinin ise Ankara'dan satın alma yoluyla müzeye kazandıııldığı tespit edilmiştir. Çalışmamızda eserlerin hiçbirinde tarih, yer ve usta bilgisine rastlanmamıs, her bir eserin tarihlendirmesi süsleme teknikleri ve motifleri göz önünde bulundurularak yapılmıştır. Buna göre incelenen eserlerin ikisinin 18-19. yüzyl, ikisinin ise 19. yüzyıl Osmanlı dönemi hattat sandıkları olduğu sonucuna ulaşılmıştır. Taşınabilir eserler olması sebebiyle sandıkların üretim merkezleri hususunda kesin bir şey söylenemese de, 8458 envanter numaralı sandığın İstanbul'dan satın alınarak müzeye getirilmesinden ve Sultan Abdülmecid'e ait bir yazı kutusuyla yaptığımı kıyaslama neticesinde İstanbul'da yapıldığı ileri sürülebilir. Diğerlerinin üretim merkezi hakkında bir veri yoktur. Fakat 6000 envanter numaralı eser, süslemelerinde kullanılan hayvan figürleri ve bunun son derece girift bir bitkisel bezemenin içine yerleştirilmesi bakımından diğer sandıklardan farklı bir üslup sergilemektedir.

Hattat sandıkları dikkatle incelendiğinde kullanılan tekniklerde ve bezeme kompozisyonlarında çeşitlilik gözlenmiştir. Tamamı ahşaptan yapılan eserlerin çift katlı rölyef, kazıma, kakma, ajur ve edirnekâri olmak üzere beş farklı teknikle işlendiği tespit edilmiştir. 6000 ve 7169 envanter numaralı eserlerde iki farklı teknik kullanılırken, diğerlerinde bir teknik kullanılmıştır. Sandıkların bezemelerinde geometrik motiflerin yalnızca 7169 envanter numaralı eserde çok küçük bir alanı kaplayacak biçimde uygulandığı görülürken, yazı yalnızca 8458 envanter numaralı sandığın kapağının içinde yer almıştır. Buna mukabil incelenen dört örneğin tamamında bitkisel süslemeye yer verilmisstir. Figür ise yalnızca 6000 envanter numaralı sandıkta girift bir bitkisel süslemenin arasına yerleştirilen tavşan, köpek, aslan ve kuş figürlerinden müteşekkildir. Eserlerin tamamı geç Osmanlı dönemi özellikleri gösterdiğinden motifler daha çok doğada gördüğümüz bitkiler ve hayvanlardan oluşmaktadır.

Hattat sandıkları, bir hattatın kullandığı hat sanatı araç gereçlerinin korunarak günümüze ulaşmasını sağlayan oldukça önemli eserlerdir. Türk İslam sanatı araştırmalarında neredeyse hiç yer verilmeyen bir konuya dikkat çekmeye çalıştı̆̆ııı bu çalışmada, Ankara Etnografya Müzesindeki hattat sandıkları tarihsel, sanatsal ve estetik boyutlarıyla analiz edilmeye çalısılmıştır. Bu ve benzeri çalışmalar, hattat 
sandıklarının Türk İslam Sanatları tarihindeki yerinin ortaya konulması ve bu alanda kaynak oluşturulması bakımından önem arz etmektedir.

\section{Extended Abstract}

The subject of this research is determined as "Calligrapher Chests in Which Calligraphy Tools are Preserved: Examples from Ankara Ethnography Museum". Throughout the Turkish-Islamic history, various tools such as reed pen, paper, ink, ink pot, scissors, sharpener, burnisher, end grain used in calligraphy and performing calligraphy, these tools had an important place. Because these tools are also adorned with precious metals. For this reason, these tools were kept in carefully prepared calligrapher chests.

In this research, we examined four chests in the Ankara Ethnography Museum. This subject has been discussed in order to introduce the calligrapher chests used for keeping and preserving calligraphy tools to future generations and to contribute these chests to the literature. In the research on this subject, sufficient information could not be obtained about calligrapher chests. However, there are few examples in the published catalogs of some museums. The calligrapher chests in the Ankara Ethnography Museum have never been mentioned in any publications up to now. All of the handworks examined within the scope of our subject are in the exhibition of Ankara Ethnography Museum. The necessary permissions were obtained from the museum, photographs and informations of the artifacts were obtained and drawings were made for detailed analysis.

Four calligrapher chests examined in our study were evaluated in terms of material, technique, form, function and decoration, then their periodic features were tried to be revealed. According to the information obtained here, it was understood that all of the handworks were made of wood. The chest with the inventory number 6000 was decorated with double-layered relief and engraving, the chest with inventory number 7169 was decorated with ivory inlay and openwork techniques, and the chests 8458 and 10725 were decorated with painting technique. All of the mentioned examples are in the form of a rectangular prism. Three of the items that we define as chests in our study are designed as boxes and one as drawers. Calligrapher chests have similarities with chests such as jewelery chests, quran chests, money drawers and laundry drawers in terms of their shapes and sizes. However, the slots in which the ink tanks will be placed, the determination of the compartments where the materials will be placed and the inventory information in the museums give us information about the functions of the calligrapher chests. Calligrapher chests are now included in Topkap1 Palace Museum, Turkish and Islamic Arts Museum, Sakıp Sabanc1 Museum, Konya Museum Directorate, Ankara Ethnography Museum and some private collections.

It can be observed that the chests of calligraphers were designed in an aesthetically elegant manner and decorated with different compositions. While geometric, figured, floral motifs and inscriptions are found in these decoration compositions, no ornamentation with objects is encountered. In addition, different motifs were used in the same handwork. There are geometric motifs in only one work. All chests have floral ornaments. Flowers with large leaves, flowers and leaves carried by curved branches, flowers with four leaves, roses and various flowers depicted with a naturalistic approach in the rococo style and rumis constitute the floral decoration. Figures were used only in the handwork with the inventory number 6000, here it is possible to see lion, dog, rabbit and bird figures. These figures, included in a floral composition, contain iconographically rich meanings such as power, strength, patience, trust, loyalty, friendship and luck. All the figures mentioned are separated from each other, symmetrically and slightly mobile in an intricate floral composition. Even dots and lines are detailed in the ornaments. The only chest where it is possible to see the writing is the calligrapher chest numbered 8458, on the inside of its cover with the signature of Sultan Abdülmecid.

None of the examples in this research had any knowledge of history, place or workman and the dating of the handworks was done with the help of ornamentation techniques and motifs. As a result of this examination, it was understood that the handworks were from the 18th and 19th century Ottoman calligraphy chests. As they are portable artifacts, there is no exact information about the place where the chests were produced. However, it is thought that the chest with inventory number 8458 was produced in 
Istanbul due to its resemblance to a writing box belonging to Sultan Abdülmecid. There is no data about the production places of other calligrapher chests.

In this study, in which we tried to draw attention to an issue that we do not come across frequently in studies on Turkish-Islamic arts, the chests of calligraphers in Ankara Ethnography Museum were evaluated aesthetically, artistically and historically, and it was tried to contribute to future studies.

Keywords: Ankara Ethnography Museum, Calligraphy Tools, Calligraphy Chests, Writing Drawers, Writing Boxes

\section{Kaynakça}

Acar, M. Ş. (1999). Türk Hat Sanatı (Araç, Gerę̧ ve Formlar). İstanbul: Antik A.Ş. Kültür Yayınları.

Anonim, (2002). Türk ve İslâm Eserleri Müzesi. İstanbul: Akbank Kültür ve Sanat Yayınları.

Anonim, (1956). Eski Cekmeceler. İstanbul: Topkapı Sarayı Müzesi Yayınları.

Arseven, C. E. (1983). Çekmece. Sanat Ansiklopedisi (Cilt 1, s. 383). İstanbul: İstanbul Milli Eğitim Bakanlı̆g1 Yayınları.

Çatalbaş, R. (2011). Türklerde Hayvan Sembolizmi ve Din İlişkisi. Turan-Sam Turan Stratejize Arastırmalar Merkęi Dergisi, 3(12), 49-60.

Çobanoğlu, A. V. (2003). Mehmed Ağa, Sedefkâr. Türkiye Diyanet Vakfi İlâm Ansiklopedisi (Cilt 28, s. 430-431). Ankara: TDV Yayınlar1.

Çoruhlu, Y. (2002). Türk Mitolojisinin Ana Hatları. İstanbul: Kabalc1 Yayınları.

Çoruhlu, Y. (2014). Türk Sanatında Hayvan Sembolizmi. Konya: Kömen Yayınları.

Kara, H. \& Aygör, E. (2020). Ankara Etnografya Müzesinde Bulunan Maktalar. Türk İslâm Medeniyeti Akademik Arastrmalar Dergisi, 15(30), 247-266.

Kara, H. (2020). Konya Müze Müdürlüğüne Bağlı Müzelerdeki Hat Sanatı Araç Gereçleri. Fulya Köksoy (Ed.), Ankara III. Uluslararası Bilimsel Arasttrmalar Kongresi Bildirileri (2-4 Ekim 2020 Ankara) Tam Metin Kitabı (Sosyal Bilimler) içinde (s. 164-188). Ankara: ISPEC Yayınları.

Kollektif, (2012). Sakep Sabancı Müresi Kitap Sanatlar ve Hat Koleksiyonu. İstanbul: Sakıp Sabancı Müzesi Yayınları.

Önder, M. (1995). Antika ve Eski Eserler Kılavuzu. Ankara: Türkiye İş Bankası Kültür Yayınları.

Sülün, M. (2006). Sanat Eserine Vurulan Kur'an Mübrü. İstanbul: Kaynak Yayınları.

Şehsüvaroğlu, H. (1987). Eski Çekmeceler. Şevket Rado (Haz.), Aletler ve Adetler (s. 16-18). İstanbul: Ak Yayinlar1.

Ünver, S. (2010). Türk Süsleme Sanatlar II. İstanbul: İşaret Yayınları.

Yücel, E. (1993). Çekmece. Türkiye Diyanet Vakfi İslâm Ansiklopedisi (Cilt 8, s. 251-252). İstanbul: TDV Yayınlar1.

URL-1: Türk Dil Kurumu. (2020, 1 Kasım). Türk dil kurumu sözlükleri içinde. Erişim adresi https://sozluk.gov.tr/ 